\title{
Greening of the agricultural sector as a condition for sustainable development of the Russian economy
}

\author{
Tatiana Marinchenko ${ }^{1, *}$ and Antonina Korolkova ${ }^{1}$ \\ ${ }^{1}$ Russian Research Institute of Information and Feasibility Study on Engineering Support of \\ Agribusiness, the Federal State Budgetary Scientific Institution (Rosinformagrotekh FSBSI), 60, \\ Lesnaya Str., Pravdinsky Township, 141261, Moscow Region, Russia
}

\begin{abstract}
Sustainable development of mankind, which consists in meeting the needs of the present day without undermining the possibilities of future generations, enshrined in the UN program documents, is becoming a necessary condition for the survival of civilization. The growing scale of global environmental problems makes it vitally important to find solutions to combine global economic growth and sustainable development of mankind with the preservation of the environment. Today, the issues of energy and resource efficiency of production are especially relevant, particularly in the agricultural sector, which environment burden has increased. In conditions of high global competition and aggravated issues of the world ecology, the country faces the task of modernizing its economy. The new national development goals of Russia directly resonate with the sustainable development goals defined by the UN and are reflected in the general policy of resource use and environmental protection. However, additional steps are needed to maintain positions in world trade. The paper formulates the prerequisites and solutions for the greening of agricultural production and identifies the leaders of the process, as well as the segment of producers, for which greening measures are factors of survival. Indicators of environmental efficiency, the use of which will make it possible to make greening measures the engine of the country's economic agricultural production, as well as goals and solutions for the greening of agricultural production are proposed.
\end{abstract}

\section{Introduction}

The world's population is growing rapidly along with the growing demand for food and raw materials. According to UN estimates, the world's population will increase by $26 \%$ up to 9.7 billion people by 2050 . In 2018 , moderate or severe food insecurity affected $26.4 \%$ of the world's population or about 2 billion people. In this aspect, the main goal of sustainable world development is to develop the main ways and means of adapting life to global changes. Sustainable development, according to the UN International Commission

\footnotetext{
*Corresponding author:9419428@mail.ru
} 
on Environment and Development, means development that meets the needs of the present generation and does not jeopardize the ability of future generations to meet their needs [1].

The concept of sustainable development is broader than the essence of greening. However, in essence there is homogeneity of final goals between socio-economic development and environmental protection. The greening of production is currently a global trend that involves limiting and reducing the natural intensity of production through the creation of technologically advanced, highly efficient and clean technologies while minimizing the environmental damage.

According to the definition of experts of the United Nations Environment Program (UNEP), the "green economy" is understood as "an economic model that leads to improved human well-being and social equality, as well as reduction of environmental risks and deficits" [2]. In essence, such an economy is low-carbon and energy and resource efficient, and includes solving social problems.

The growing demand for food has led to the widespread adoption of industrial agricultural technologies using synthetic chemicals as a quick and effective strategy to increase crop yields and productivity in livestock production accompanied by devastating impacts on human health, the environment and the development of resistant strains of pests and pathogens [3]. Загрязнение окружающей среды достигло катастрофических масштабов. Concentrations of climate-warming carbon dioxide in the atmosphere have hit record highs, scientists have said. The data released by the Scripps Institution of Oceanography, University of California San Diego, shows atmospheric concentrations of the greenhouse gas in March averaged 417.14 parts per million (ppm), a new record high. The UK's Met Office predicts monthly concentrations of carbon dioxide, the main driver of rising temperatures and the climate crisis, will peak in 2021 at about $419.5 \mathrm{ppm}$ [4].

In the world, many countries are currently implementing anti-crisis programs of an integrated approach that takes into account the foundations of sustainable development: economic growth, social development and environmental protection [5]. An example is a road map being implemented in the UK, according to which the greening of production should affect all industries and activities and create about 100,000 new jobs. The document sets out an algorithm for the development and implementation of mechanisms until 2050 [16].

A study of the environmental agenda in international trade leads to a conclusion about the widespread and strengthening of measures to protect the environment. Today, there is a change from the anthropocentric approach to the ecocentric one, which forms new rules of interaction [7]. An example is the EU, which is one of the leaders on the environmental agenda. Therefore, the trends in the penetration of the environmental agenda into international trade must be taken into account in order to preserve and develop the export potential of the Russian agribusiness.

\section{Materials and methods}

The research subject is the process of the production greening in the world and the Russian Federation in the context of sustainable development goals, including those in the field of agricultural production. The purpose of the work is to search for indicators of the environmental efficiency of measures, objectives and ways to solve them in the field of the greening of agricultural production, to identify factors aimed at developing the greening and stimulating producers that are leaders of the process, and assessing the adequacy of the measures provided for by program documents and regulations to solve the problems of production greening. The study was based on a general scientific methodology using the methods of monographic, comparative, factorial and logical analysis, as well as the expertanalytical method. The material base was statistical information, the results of scientific 
research of institutions, the papers of leading domestic and foreign scientists in the field of environmental research, as well as regulatory documents, legislative acts and documents that establish strategic guidelines for the development of the country and the industry.

\section{Results and Discussion}

In the Russian Federation, the goals of production greening are reflected in the general policy of resource use and environmental protection. A number of adopted documents directly relate to this issue, e.g. "Climate Doctrine" (2009), Decree No. 752 of the President of the Russian Federation titled "On reducing greenhouse gas emissions,' 'Fundamentals of state policy in areas of environmental development of Russia for the period up to 2030" (2012), etc.

At the moment, the environmental legislation of Russia is a set of documents and regulations consisting of more than 500 papers. Particular attention is paid to environmental issues related to the sustainable socio-economic development of the country. In 2020, the first "Voluntary National Review of the Implementation of the 2030 Agenda for Sustainable Development" was presented, which contained the results of a comprehensive monitoring of the socio-economic development of Russia and the development of the strategic planning system. According to the survey in Russia for 2015-2018, the amount of hazardous class I waste generated (extremely hazardous) decreased four times, namely, from 80,000 to 20,000 metric tons. With the general growth of production and consumption waste, most of them $(98.2 \%$ in 2018$)$ are hazard class $\mathrm{V}$ waste (the lowest environmental impact) $[7,8]$.

The main document of strategic planning in the field of ecology that reflects the goals, objectives and mechanisms for the implementation of state policy in the field of environmental safety, is the Strategy for Environmental Safety of the Russian Federation for the period up to 2030. The document conceptually lays down the balancing of the interests of economic and social development and attention to the environmental issue in the long term, since the sustainable development can be achieved only in the balance of the components (Fig. 1).

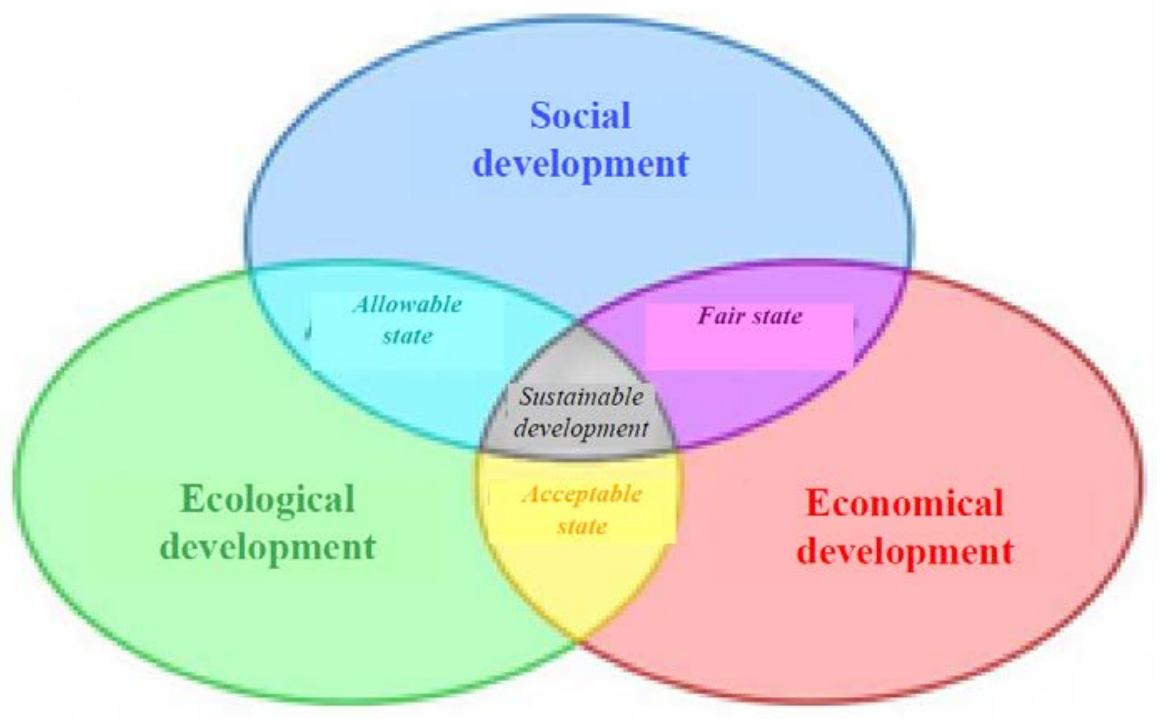

Fig. 1. Environmental safety strategy concept. 
This approach is reflected in the general policy of resource use and environmental protection and available legal and economic instruments. The main task of the Russian economy in the medium and long term is to move away from the raw material model of the economy $[9,10]$.

Promising sectors of the environmental market in Russia are the market for water and air pollution control, wastewater treatment, and waste management and recycling [11]. Russia while possessing vast territories $\left(17\right.$ million $\left.\mathrm{km}^{2}\right)$, according to the Global Footprint Network (GFN), has a large reserve of biocapacity (the ability of ecosystems to recover) being equal to $35 \%$ as of 2016 , which put it on the fourth place in the world by this indicator [12]. At the same time, as of 2011, the difference between the ecological footprint (the area of biologically productive territory and water area required for the production of human resources and the absorption of waste) and biocapacity in Russia was the lowest since 1994. Since then, the ecological footprint has been declining and biocapacity reserve of the territory of Russia has been grown (figure 2).

8
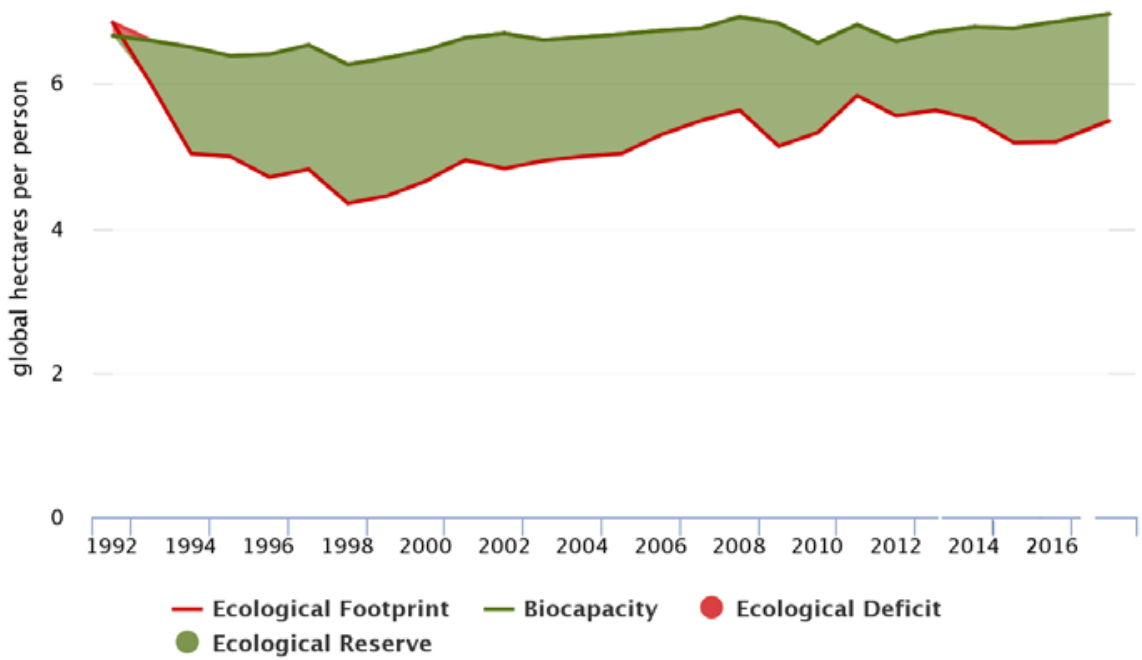

Clobal Footprint Network, 2021 National Footprint and Biocapacity Accounts

Fig. 2. Measurements of Russia's Ecological Footprint and Biocapacity in 1992-2016.

The data of the GFN study allow us to draw a conclusion about the change in attitudes towards the environment in Russia.

Today, the degree of agricultural development, and, in the future, the level of national food security, and the public health and the quality of life, are largely ensured by innovative developments in the field of alternative agriculture, the preservation of natural resources and, above all, land as the main production facility [13].

Large companies perceive increasing the sustainability of production based on environmental standards as an integral component of development. They fund environmental research, implement international standards, and use environmental reporting and other environmental policy instruments. Thus, they become one of the driving forces behind the greening of production in this country. Often this is due to the penetration of the environmental agenda into international trade and the way to protect against negative effects.

The agribusiness is the most important inter-industrial sector of the global economy. The need to implement strategies for the greening of agricultural production is due to its 
growing impact on the environment, the tasks set for energy and resource conservation and the need to ensure food security. Greening measures are focused on restoration of natural soil fertility; increasing crop yields and animal productivity; improving the quality of agricultural products; introduction and adaptation of energy and resource saving technologies [3]. Currently, the Federal Scientific and Technical Program for the Development of Agriculture for 2017-2025 is being implemented, which prioritizes the policy of transition to highly productive and environmentally friendly agricultural and aquaculture, storage and efficient processing of agricultural products, and creation of safe and high-quality food products.

Today, there is an active discussion of the methodology, in particular, the search and selection of indicators of environmental performance and comparison of their effectiveness to determine target indicators and their values. Several groups of indicators can be distinguished, the use of which will make it possible to make greening measures the engine of the country's economic agricultural production (Table 1) [3, 14, 15].

Table 1. Greening indicator groups and their potential.

\begin{tabular}{|c|c|}
\hline Indicator group & Potential effect \\
\hline $\begin{array}{l}\text { Resource potential of } \\
\text { greening }\end{array}$ & $\begin{array}{l}\text { Improving efficiency of using natural resources (forest, fish, water, } \\
\text { agricultural land, etc.), capital management (reducing economic } \\
\text { damage by taking into account environmental risks), and using human } \\
\text { capital, including that by improving the state of the environment } \\
\text { (reducing morbidity, increasing life expectancy) }\end{array}$ \\
\hline $\begin{array}{ll}\text { Efficiency } & \text { of } \\
\text { backbone sectors } & \end{array}$ & $\begin{array}{l}\text { Improving energy supply, technologies for agriculture and forestry, } \\
\text { transport links, waste disposal and recycling, and water resources } \\
\text { management }\end{array}$ \\
\hline $\begin{array}{l}\text { Investments in the } \\
\text { greening } \\
\text { agricultural } \\
\text { production }\end{array}$ & $\begin{array}{l}\text { Improving the environmental friendliness of agricultural machinery } \\
\text { (focusing on alternative fuel sources), reducing greenhouse gas } \\
\text { emissions, introducing waste-free production technologies, recycling } \\
\text { industrial waste, energy-passive construction, reducing the energy } \\
\text { intensity of production, switching to renewable energy sources (RES), } \\
\text { etc. }\end{array}$ \\
\hline Innovative activity & $\begin{array}{l}\text { Creation of a favorable competitive environment for innovative } \\
\text { activity of enterprises and implementation of environmental standards } \\
\text { and regulations }\end{array}$ \\
\hline Labor market & $\begin{array}{l}\text { Involvement of the able-bodied population in economic activities, } \\
\text { stimulation of the development of small forms of farming }(\mathrm{MFH}) \text { is } \\
\text { the main factor in the greening of agricultural production }\end{array}$ \\
\hline Habitat quality & $\begin{array}{l}\text { Reducing the impact of negative anthropogenic impact: reducing } \\
\text { emissions, chemical load, disposal and recycling of waste; } \\
\text { introduction of environmentally friendly technologies in food } \\
\text { production and agriculture by increasing environmental activity. }\end{array}$ \\
\hline
\end{tabular}

With traditional approaches to assessing the effectiveness of investments, the greening is a high-cost and long-term area with effects consistent with the UN Sustainable Development Goals (SDGs), which is difficult to implement without government support. For example, today in Russia, renewable energy in the energy balance of Russia is about $2 \%$. Thanks to the program of state support for the development of renewable energy, about $6 \mathrm{GW}$ of renewable energy sources will be built by 2024 and should grow up to $4 \%$ to $5 \%$ according to data announced at the Global Manufacturing \& Industrial Summit (GMIS2020). Since the Russian Federation has a large potential for many types of energy, it is possible to achieve a low cost of electricity, heat and fuel and decentralization of energy supply based on the development of small-scale energy. It can be distinguished bioenergy, geothermal heat pumps, solar hot water supply systems, heat accumulators, unmanned mini-hydroelectric power plants, solar pumps, hydraulic rams, and other 
domestic projects. There are unique projects in the field of renewable energy sources that have no analogues in the world, for example, in the field of petrothermal energy, i.e. the use of thermal energy of "dry" rocks of the earth's crust with the subsequent generation of electricity and heat [3].

The effectiveness of the application of measures in the agribusiness for the long term regarding the greening can be determined by the degree of achievement of goals taking into account possible solutions (Table 2).

Table 2. Objectives and options for solutions for the greening of agribusiness.

\begin{tabular}{|c|c|c|}
\hline Sector & Objectives & $\begin{array}{c}\text { Solutions } \\
\end{array}$ \\
\hline $\begin{array}{l}\text { Power generation } \\
\text { (electricity, heat, oil } \\
\text { and gas) }\end{array}$ & $\begin{array}{l}\text { Increasing energy efficiency, } \\
\text { switching to alternative } \\
\text { energy sources, access of the } \\
\text { population to cheap energy }\end{array}$ & $\begin{array}{l}\text { Implementation of projects in wind, } \\
\text { solar, hydropower, geothermal and } \\
\text { bioenergy, introduction of heat } \\
\text { accumulators, systems, etc. }\end{array}$ \\
\hline Water supply & $\begin{array}{l}\text { Rational use of water } \\
\text { resources, ensuring the quality } \\
\text { of water supply }\end{array}$ & $\begin{array}{l}\text { Monitoring, regional water quality } \\
\text { improvement programs, wastewater } \\
\text { treatment, and water protection }\end{array}$ \\
\hline Recycling & $\begin{array}{l}\text { Reducing environmental harm } \\
\text { due to agricultural production, } \\
\text { increasing the level of } \\
\text { recycling of agricultural waste }\end{array}$ & $\begin{array}{l}\text { Monitoring, waste management, } \\
\text { implementation of technologies for } \\
\text { waste-free food production and } \\
\text { processing of raw materials and } \\
\text { recycling }\end{array}$ \\
\hline $\begin{array}{l}\text { Agricultural } \\
\text { production } \\
\text { processing }\end{array}$ & $\begin{array}{lr}\text { Increasing } & \text { agricultural } \\
\text { production } & \text { without } \\
\text { deteriorating soil fertility and } \\
\text { ecology in general }\end{array}$ & $\begin{array}{l}\text { Implementation of systems of smart } \\
\text { farming and production, biological } \\
\text { means of protecting plants and } \\
\text { animals, the use of bio- and nano- } \\
\text { materials, and land reclamation }\end{array}$ \\
\hline $\begin{array}{l}\text { Agricultural } \\
\text { machinery }\end{array}$ & $\begin{array}{l}\text { Decrease in diesel / gasoline } \\
\text { traffic, and export promotion }\end{array}$ & $\begin{array}{l}\text { Introduction of alternative fuels, } \\
\text { and implementation of efficient } \\
\text { logistics }\end{array}$ \\
\hline $\begin{array}{l}\text { Conservation of } \\
\text { natural biocenoses } \\
\text { and biodiversity }\end{array}$ & $\begin{array}{l}\text { Conservation of the forest } \\
\text { fund and its protection, natural } \\
\text { biocenoses, flora and fauna, } \\
\text { and protection of rivers and } \\
\text { reservoirs }\end{array}$ & $\begin{array}{l}\text { Introduction of monitoring systems } \\
\text { for forestry, agriculture and water } \\
\text { bodies, and measures to restore } \\
\text { ecosystem biodiversity }\end{array}$ \\
\hline $\begin{array}{l}\text { Agricultural } \\
\text { construction }\end{array}$ & $\begin{array}{l}\text { Ensuring the quality of the } \\
\text { habitat }\end{array}$ & $\begin{array}{l}\text { Energy-passive } \\
\text { technologies }\end{array}$ \\
\hline Balanced diet & $\begin{array}{l}\text { Balanced diet, food quality, } \\
\text { and reducing food waste }\end{array}$ & $\begin{array}{l}\text { Monitoring } \\
\text { introducing certification systems, } \\
\text { traceability, product safety control } \\
\text { (Hazard Analysis and Critical } \\
\text { Control Points [HACCP]), } \\
\text { improving logistics, and } \\
\text { stimulating exports }\end{array}$ \\
\hline
\end{tabular}

Stimulation of greening should be reflected in the practical implementation of the latest scientific achievements and replication of best practices, which implies transferring production to the principles of the best available technology that provides for a system of payments and penalties for environmental pollution, ensuring monitoring, and eliminating the practice of temporary agreed emission permits and the past environmental damage. When investing in resource-saving structural restructuring while radically changing its technological basis today, it is possible to achieve its greening and reducing the cost of eliminating the negative environmental consequences of technogenic economic development in the future. 
The study of the environmental agenda at the international level allows us to conclude that the measures to protect the environment are spreading and strengthening. Today we can observe the change of the anthropocentric approach to the ecocentric one, around which new rules of interaction are being formed. A number of countries and associations are already following this path, for example the European Union, which is one of the leaders on the environmental agenda. At the same time, special attention should be paid to the penetration of the environmental agenda into international trade, especially into the country's traditional export positions.

Several key strategic documents in this area have been adopted in Russia, however, to maintain positions in world trade, additional coordinating steps on the part of the state and significant efforts on the part of business are required. Large companies are very active in terms of greening: they finance environmental programs, introduce environmentally friendly technologies, apply international standards, and use environmental reporting and other environmental policy instruments. Thus, they become one of the driving forces behind the greening of production in this country. Moreover, such activity is largely a reaction to the changing landscape in international trade, i.e. a response to the penetration of the environmental agenda and a way to protect against negative effects [16]. Therefore, measures for the greening of agricultural production of medium-sized enterprises are essential for their competitiveness in the domestic market and strengthening of their positions in world market.

Small forms of farming are a significant reserve for the growth of environmentally friendly agricultural production. According to the 2016 All-Russian Agricultural Census, there are 36,000 agricultural enterprises in the country, 24,300 of which are micro and small enterprises, 174,800 are peasant (farm) enterprises including individual entrepreneurs, and 23.5 million personal subsidiary and other individual farms [8]. At the same time, the share of small farms in agriculture accounts for $45 \%$ of the gross output of the industry and more than $50 \%$ of the area under crops. To support their development, the federal project titled "Creation of a support system for farmers and the development of rural cooperation" has been implementing since 2019, within the framework of which 5.4 billion rubles were allocated in 2019. 83 constituent entities of the Russian Federation are implementing regional programs from the regional budgets and 595.6 million rubles have been allocated for support.

An increase in the share of peasant (farm) enterprises and an increase in their number largely depend on the development of such forms of integration as agricultural consumer cooperatives. This form has proven its effectiveness and has become widespread in the world while remaining the leading segment in the development of the rural economy. Thus, the share of the cooperative sector in the rural economy of the EU countries was $40 \%$ in 2018 and ranged from 20\% (Latvia) to 74\% (Finland). The cooperative sector in agriculture occupies a significant share in the Netherlands, Denmark, Sweden, and France from $68 \%$ to $57 \%$ [17]. Taking into account the share of production by small forms of farming, it is necessary to perceive as the main potential of environmentally friendly agricultural production. Stimulating their development allows simultaneously solving important social problems consonant with sustainable development goals, such as increasing employment of the rural population; assistance to the development of rural areas, social development of rural settlements; preservation of national traditions and rural way of life, etc.

\section{Conclusion}

Modern agricultural production has led to the widespread introduction of industrial resource-intensive technologies, which lead to inefficient consumption and loss of natural resources, and an increase in environmental pollution. An integrated approach that takes 
into account economic growth, social development and environmental protection is being applied around the world.

The environmental legislation of Russia is a set of documents and regulations of more than 500 papers, which together represent the concept of socio-economic transformations aimed at meeting human needs without harming future generations. The tools are the responsible exploitation of natural resources, investments in the greening of production, in the development of energy-saving technologies and the determination of responsibility for the damage caused.

Several groups of indicators can be distinguished, the use of which will be effective: the resource potential of greening, the efficiency of backbone sectors, investments in the greening of agricultural production, innovative activity, as well as the labor market and the quality of the living environment. It is advisable to determine the effectiveness of greening measures by the degree of achievement of goals.

Large Russian companies are active in terms of greening production being one of the driving forces behind greening production in this country, which needs to be adopted by medium and small enterprises to maintain their competitiveness in the domestic market and strengthen their positions in the world market. At the same time, small farms are seen as the main potential for environmentally friendly agricultural production, since they account for $45 \%$ of the industry's gross output and more than $50 \%$ of the cultivated area. Their state support and stimulation of development allows solving social tasks consonant with the sustainable development goals, thereby they are a potential for increasing environmentally friendly production. The quality of life of the country's population in the future will be a cumulative consequence of the effectiveness of modern solutions to environmental problems and ways to achieve the set goals.

\section{References}

1. 17 Goals to transform our world, https://www.un.org/sustainabledevelopment/

2. Green industrial policy: concept, policies, country experiences UNEP (2011), www.unep.org/greeneconomy

3. T.E. Marinchenko, E3S Web of Conferences 193, 01046 (2020)

4. Carbon dioxide levels in atmosphere reach record high, https://www.theguardian.com/environment/2021/apr/07/carbon-dioxide-levels-inatmosphere-reach-record-high

5. A. Purwanto, J. Sušnik, F.X. Suryadi, C. de Fraiture, Sustainability (Switzerland) 13(4), 1-18 (1919)

6. D. Benson, A.K. Gain, J.J. Rouillard, Water Alternatives 8(1), 756-773 (2015)

7. A.A. Stuglev, V.Yu. Salamatov, E.K. Gubenko, V.O. Kolomin, A.V. Tangaeva, D.A. Zhurbenko, Environmental agenda and international trade: from contradictions to opportunities information and analytical digest (Roscongress, 2020)

8. Voluntary National Review of the Implementation of the 2030. Agenda for Sustainable Development (2020)

9. O.Y. Voronkova, D.F. Islamutdinova, O.G. Gordeyeva, I.I. Frolova, I.V. Fedulova, A.E. Zhminko, European Research Studies Journal 21(3), 28-38 (2018)

10. A.K. Apazhev, V.N. Berbekov, Y.A. Shekikhachev, L.M. Hazhmetov, G.H. Bakuev, L.Z. Shekikhacheva, IOP Conf. Series: Materials Science and Engineering 919(6), $062002(2020)$

11. E.V. Kyul, A.K. Apazhev, A.B. Kudzaev, N.A. Borisova, Indian Journal of Ecology 44(2), 239-243 (2017)

12. Global footprint network. national footprint accounts. The Russian Federation, https://data.footprintnetwork.org/\#/countryTrends?cn=185\&type=BCpc,EFCpc 
13. L.V. Kashirskaya, O.Yu. Voronkova, A.A. Sitnov, R.A. Shichiyakh, M.G. Kudinova, I.N. Sycheva, Journal of environmental management and tourism 10.3(35), 651-659 (2019)

14. A.K. Sharipov, S.A. Naubetova, S.S. Kulshenbaeva, S.K. Nurbekova, A.E. Dairbekova, M.K. Baimyrzaeva, Espacios 39.22, 35 (2018)

15. V.G. Zakshevsky, O.G. Charykova, I.N. Merenkova, IOP Conference Series: Earth and Environmental Science 012007 (2019)

16. I. Donnik, B. Voronin, O. Loretts, Indian Journal of Science and Technology 9.14, 2-5 (2016)

17. N.A. Kuznetsova, A.V. Ilyina, A.P. Korolkova, T.E. Marinchenko, IOP Conference Series: Earth and Environmental Science 677(2), 022043 (2021) 